\title{
Effects of ion beam irradiation on mutation induction and nuclear DNA content in chrysanthemum
}

\author{
Hiroyasu Yamaguchi*1,3), Akemi Shimizu1), Yoshihiro Hase ${ }^{2)}$, Atsushi Tanaka ${ }^{2)}$, Naoya Shikazono'), \\ Konosuke Degi ${ }^{1,4)}$ and Toshikazu Morishita ${ }^{1,5}$ \\ 1) Institute of Radiation Breeding, National Institute of Agrobiological Sciences, 2425 Kamimurata, Hitachi-Omiya, Ibaraki 319-2293, \\ Japan \\ 2) Quantum Beam Science Directorate, Japan Atomic Energy Agency, 1233 Watanuki-machi, Takasaki, Gunma 370-1292, Japan \\ 3) Present address: National Institute of Floricultural Science, 2-1 Fujimoto, Tsukuba, Ibaraki 305-8519, Japan \\ 4) Present address: Miyakojima Branch, Okinawa Prefectural Agricultural Research Center, 2071-40 Nishizato, Hirara, Miyakojima, \\ Okinawa 906-0012, Japan \\ 5) Present address: National Agricultural Research Center for Hokkaido Region (Memuro), Shinsei, Memuro, Hokkaido 082-0081, \\ Japan
}

We investigated the effects of ion beams, in comparison to gamma rays, on mutation induction and nuclear DNA content as an index of radiation damage in Chrysanthemum morifolium. Leaf segments were irradiated with $220 \mathrm{MeV}$ carbon ions (mean linear energy transfer $=107 \mathrm{keV} / \mu \mathrm{m}), 320 \mathrm{MeV}$ carbon ions $(76 \mathrm{keV} / \mu \mathrm{m})$, $100 \mathrm{MeV}$ helium ions $(9 \mathrm{keV} / \mu \mathrm{m})$, and gamma rays. The nuclear DNA content was measured and frequency of flower color mutations was investigated in regenerated plants. The number of plants with reduced nuclear DNA content increased with increasing irradiation doses of $320 \mathrm{MeV}$ carbon ions, $100 \mathrm{MeV}$ helium ions, and gamma rays. In contrast, they did not increase with $220 \mathrm{MeV}$ carbon ions, even when the dose was increased. Irradiation treatment with 220 and $320 \mathrm{MeV}$ carbon ions and gamma rays had a similar effect on mutation induction, while the effect of $100 \mathrm{MeV}$ helium ions was not as great. Thus, the effects of irradiation treatments on mutation induction and nuclear DNA content differed according to the type of ion beams. $220 \mathrm{MeV}$ carbon ion beam seemed to be the most appropriate among the three types of ion beams because it gave a high mutation frequency with low damage to chromosomes.

Key Words: chrysanthemum, flower color mutation spectrum, gamma rays, ion beams, mutation frequency, nuclear DNA content.

\section{Introduction}

Chrysanthemum is a widely cultivated ornamental plant worldwide. Mutation is an important tool in chrysanthemum breeding. Many mutant cultivars have been produced by spontaneous mutations (sports) and induced artificially by gamma or X-rays.

In Japan, ion beams that consist of ion particles, accelerated by a cyclotron, have been used to attempt to induce mutations since the 1990s. Ion beams have high linear energy transfer (LET), and thus, greater biological effects compared to low LET radiation such as gamma and X-rays. Thus, ion beams are expected to produce higher mutation frequencies and novel mutants. It has been demonstrated that ion beams induce mutations at high frequency and produce broad mutation spectrum, including novel mutants, in Arabidopsis

Communicated by T. Nishio

Received June 4, 2010. Accepted October 11, 2010.

*Corresponding author (e-mail: yhiroya@affrc.go.jp)
(Hase et al. 2000, Shikazono et al. 2003, Tanaka et al. 1997, 2002). Recently, mutation induction by ion beam irradiation has been carried out in various plants, particularly ornamental plants such as carnation (Okamura et al. 2003), cyclamen (Sugiyama et al. 2008), dahlia (Hamatani et al. 2001), Delphinium (Chinone et al. 2008), Dianthus (Sugiyama et al. 2008), Limonium (Chinone et al. 2008), orchid (Affrida et al. 2008), osteospermum (Iizuka et al. 2008), petunia (Miyazaki et al. 2002), rose (Hara et al. 2003, Yamaguchi et al. 2003), torenia (Miyazaki et al. 2006, Sasaki et al. 2008), and verbena (Kanaya et al. 2008).

The use of ion beams for inducing mutations in chrysanthemum breeding has also been attempted (Furutani et al. 2008, Nagatomi et al. 1998, Shirao et al. 2007, Suzuki et al. 2005, Ueno et al. 2005, Wakita et al. 2008, Watanabe et al. 2008). Thus, ion beam-specific flower color mutants that could not be obtained using gamma rays were obtained by the abovementioned programs (Nagatomi et al. 1998). Moreover, new mutant varieties with different flower colors (Nagatomi et al. 2003) and reduced lateral buds (Ueno et al. 
2005) have been developed. Thus, ion beams can produce useful mutations for chrysanthemum breeding.

Although radiation treatment induces mutations, it causes radiation damage. Konzak et al. (1965) suggested that not only mutation induction effect but also the plant damage caused by irradiation treatment, such as chromosomal aberrations, should be considered for the use of any mutagen in plant breeding. Reduction in chromosome number was reported in chrysanthemums irradiated with gamma or X-rays (Dowrick and El-Bayoumi 1966, Ichikawa et al. 1970). Reduction in chromosome number is generally undesirable in the development of commercial varieties of chrysanthemums because it is correlated with reduction in the diameter of inflorescence (Ichikawa et al. 1970). Therefore, it is necessary to consider radiation damage to chromosomes in addition to mutation frequency in chrysanthemum breeding. However, the influence of ion beam irradiation on chromosomes has not been clarified.

The nuclear DNA content is easily measured by flow cytometry. The gain or loss of a single chromosome can be detected by this method, as shown in Musa (Roux et al. 2003), ryegrass (Barker et al. 2001), and wheat-rye addition lines (Bashir et al. 1993, Pfosser et al. 1995). Moreover, Yamaguchi et al. (2008) reported that nuclear DNA content of chrysanthemums decreased with increasing dose and dose rate of gamma rays, indicating that the nuclear DNA content could be used as an index of radiation damage.

In this study, we investigated the effects of ion beam irradiation on mutation induction and examined the nuclear DNA content as an index of radiation damage in chrysanthemums. Furthermore, the spectrum of flower color mutations was compared to those produced using gamma rays.

\section{Materials and Methods}

\section{Plant materials}

The chrysanthemum (Chrysanthemum morifolium) cultivar 'Taihei' was used for this study.

\section{Irradiation treatment and tissue culture}

Leaf segments $(10 \times 5 \mathrm{~mm})$ were cut from in vitro plants and placed on MS medium (Murashige and Skoog 1962) supplemented with $1 \mathrm{mg} / \mathrm{l}$ 6-benzylaminopurine (BA), $0.2 \mathrm{mg} / 1$ 1-naphthylacetic acid (NAA), 2\% sucrose, and $0.9 \%$ agar in a $6-\mathrm{cm}$ petri dish. The dishes were sealed with polyimide film.

After 3-4 days, the leaf segments were irradiated with $220 \mathrm{MeV}$ carbon ions (mean LET $107 \mathrm{keV} / \mu \mathrm{m}$ ) at doses of 1, 2, 3 and $5 \mathrm{~Gy} ; 320 \mathrm{MeV}$ carbon ions (mean LET $76 \mathrm{keV} /$ $\mu \mathrm{m})$ at doses of 1, 2, 3 and $5 \mathrm{~Gy}$; and $100 \mathrm{MeV}$ helium ions (mean LET $9 \mathrm{keV} / \mu \mathrm{m}$ ) at doses of 2, 5, 10 and $15 \mathrm{~Gy}$ generated by an AVF-cyclotron (Japan Atomic Energy Agency, Takasaki, Japan). Gamma rays were applied at doses of 10, 20, 30 and 40 Gy at a dose rate of 10 Gy per hour in the gamma room of the Institute of Radiation Breeding (National Institute of Agrobiological Sciences, Hitachi-Omiya, Japan).
After irradiation treatment, the leaf segments were transferred onto MS medium supplemented with $1 \mathrm{mg} / \mathrm{l} \mathrm{BA}$, $0.2 \mathrm{mg} / 1 \mathrm{NAA}, 2 \%$ sucrose, and $0.9 \%$ agar in $100-\mathrm{ml}$ conical beakers to induce calluses. After 17 or 18 days, the leaf segments were transferred onto MS medium supplemented with $1 \mathrm{mg} / 1 \mathrm{BA}, 0.1 \mathrm{mg} / \mathrm{l} \mathrm{NAA}, 2 \%$ sucrose, and $0.9 \%$ agar in $100-\mathrm{ml}$ conical beakers to allow shoots to regenerate.

\section{Regeneration rate}

The regeneration rate was investigated 6 weeks after transferring to the regeneration medium. Irradiation treatments were repeated four times for the 220 and $320 \mathrm{MeV}$ carbon ion beams and the $100 \mathrm{MeV}$ helium ion beam and five times for gamma rays, using 60-100 leaf segments per irradiation treatment. The regeneration rates were determined as the ratio of the number of leaf explants from which one or more shoots regenerated to the number of irradiated leaf explants.

\section{Flower color mutation}

Only one shoot was taken from each leaf segment to eliminate duplication of the mutated shoots originating from a single mutated cell. These were cultured on MS medium supplemented with $1 \%$ sucrose and $0.9 \%$ agar. Rooted shoots were acclimatized and then transplanted in a field in June. In November, flower color mutations were investigated using 128-399 plants per irradiation treatment, shown in Table 1. Mutation frequencies were determined as the ratios of the number of flower color mutants to the number of investigated plants.

\section{Flow cytometric analysis}

The nuclear DNA content was measured by flow cytometric analysis according to Yamaguchi et al. (2008). Leaves of the garden pea (Pisum sativum cv. Narikoma Sanjunichi) were used as an internal reference standard and the nuclear DNA content of the sample was determined by comparing the peak position of the nuclei of the garden pea with that of the sample. Each plant was measured twice for its nuclear DNA content using two leaves on two different days. A plant maintained by vegetative propagation but not irradiated was used as a control. A control sample was measured after approximately every 10 samples and at the beginning and end of each day. Relative nuclear DNA content was expressed as the ratio of the nuclear DNA content of the investigated plants divided by that of the non-cultured control plants; the data for both control and experimental plants were collected on the same day. Fifty regenerated plants were used from each irradiation treatment as follows: 1, 2 and $3 \mathrm{~Gy}$ of the $220 \mathrm{MeV}$ carbon ion beam; 2, 3 and $5 \mathrm{~Gy}$ of the $320 \mathrm{MeV}$ carbon ion beam; 2, 5 and $10 \mathrm{~Gy}$ of the $100 \mathrm{MeV}$ helium ion beam; and 10,20 and $30 \mathrm{~Gy}$ of gamma rays, and from non-irradiated leaf explants.

\section{Plant size}

In order to investigate the relationship of leaf size and 
diameter of inflorescence to nuclear DNA content, 38-48 regenerated plants with $0.94-1.01$ relative nuclear DNA content and no change in leaf and flower shape were selected from each irradiation treatment using $220 \mathrm{MeV}$ carbon ion beam and gamma rays. A plant maintained by vegetative propagation without irradiation treatment was used as a control.

Four rooted cuttings from each plant were planted in four blocks with one plant per block using a randomized block design in July. Seven days later, the terminal buds of the cuttings were pinched off, and three lateral shoots per plant were allowed to develop. They were grown under natural day length, and the uppermost flower of each shoot was allowed to develop by disbudding the lateral buds. The length and width of the five largest leaves and the diameter of inflorescence in each of three shoots per plant were measured in November.

\section{Results}

\section{Regeneration}

Callus formation was unaffected by the irradiation dose within the range of the dose of each ion beam and gamma rays used in this study. However, shoot regeneration from calluses was affected by the irradiation dose; the regeneration rate decreased with increasing irradiation dose (Fig. 1). The regeneration rate was $50 \%$ at $3 \mathrm{~Gy}$ of the $220 \mathrm{MeV}$ carbon ion beam, $5 \mathrm{~Gy}$ of the $320 \mathrm{MeV}$ carbon ion beam, $10 \mathrm{~Gy}$ of the $100 \mathrm{MeV}$ helium ion beam, and $25 \mathrm{~Gy}$ of the gamma rays. Thus, the effects on regeneration increased with increasing LET.

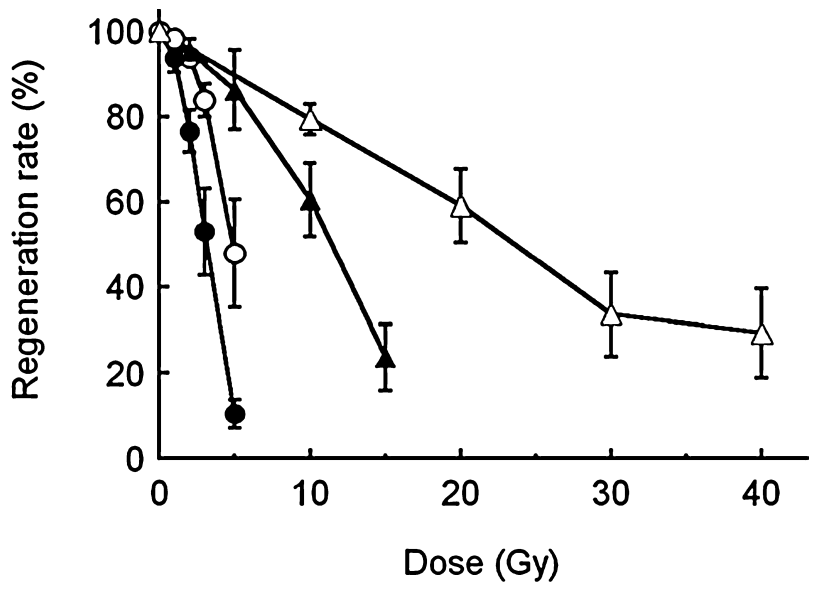

Fig. 1. Effect of ion beam and gamma ray irradiation on regeneration in chrysanthemum. $220 \mathrm{MeV}$ carbon ion beam; $\bigcirc: 320 \mathrm{MeV}$ carbon ion beam; $\boldsymbol{\Delta}$ : $100 \mathrm{MeV}$ helium ion beam; $\triangle$ : gamma rays; Vertical bars indicate $\mathrm{SE}(\mathrm{n}=4$ for 220 and $320 \mathrm{MeV}$ carbon ion beams and $100 \mathrm{MeV}$ helium ion beam; $\mathrm{n}=5$ for gamma rays).

\section{Nuclear DNA content}

The relative nuclear DNA content in plants that were regenerated from non-irradiated leaf segments ranged from 0.98 to 1.03 , with an average of 1.00 (Fig. 2). In contrast, some plants that were regenerated from irradiated leaf segments had low relative nuclear DNA content. The lowest relative nuclear DNA content was 0.92 , that is, an $8 \%$ reduction compared to the control plant, equivalent to a reduction of approximately four of the 54 chromosomes of $C$. morifolium.

In all irradiation treatments in this study, the number of plants with a relative nuclear DNA content below 0.97, which is below the range for plants regenerated from non-

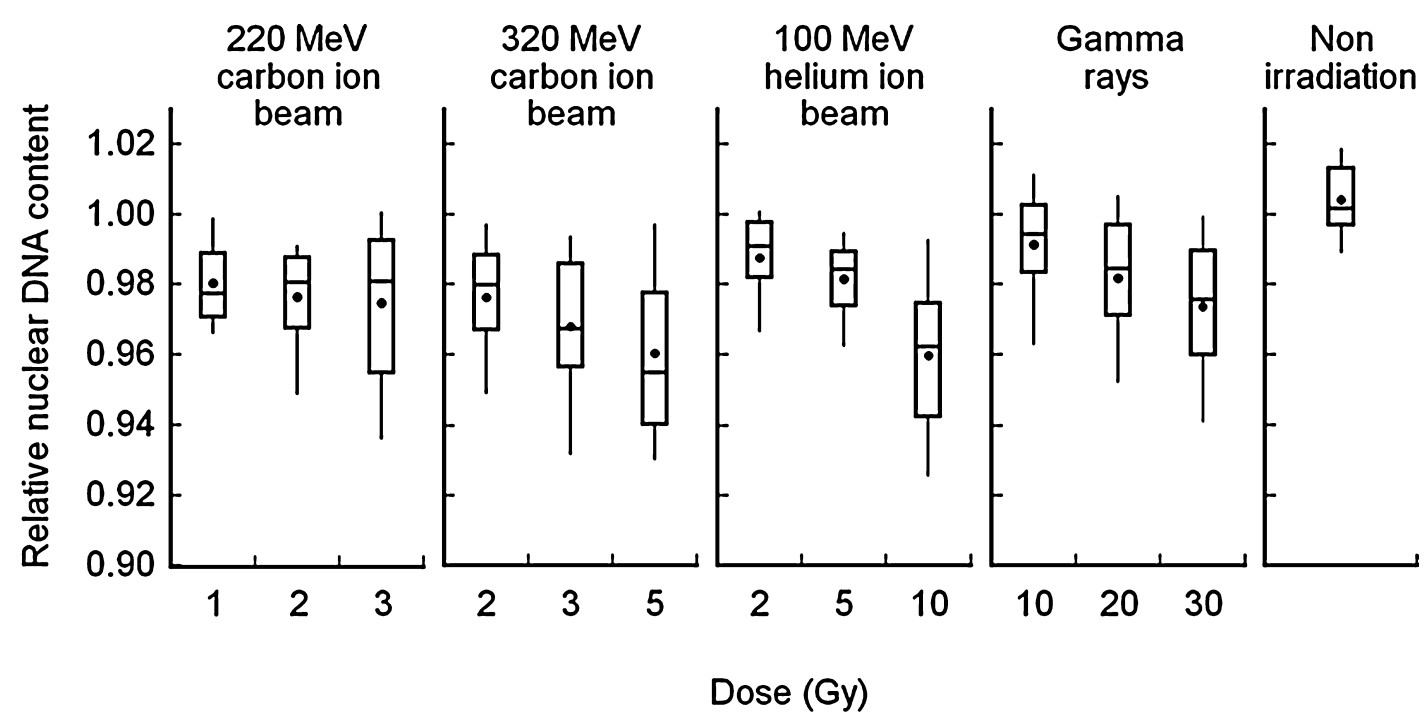

Fig. 2. Effect of ion beam and gamma ray irradiation on nuclear DNA content in chrysanthemum. The bottom and top of the box represent the $25^{\text {th }}$ and $75^{\text {th }}$ percentile, respectively. The band in the box represents the median. The ends of the whiskers represent the $10^{\text {th }}$ and $90^{\text {th }}$ percentile, respectively. Dots plotted inside the box represent the average data. Relative nuclear DNA content is expressed as the ratio of the nuclear DNA content of the investigated plants divided by that of the non-cultured control plants. Data shown in "Non irradiation" were taken from the regenerated plants from non-irradiated leaf explants. 
irradiated leaf segments, increased significantly (chi-square test for independence, $P<0.01$ ), and the average nuclear DNA content was significantly lower (Kruskal-Wallis test, $P<0.01)$ than that of plants regenerated from non-irradiated leaf segments. Thus, irradiation treatment caused a reduction in the nuclear DNA content in chrysanthemum.

The change in the nuclear DNA content according to the irradiation dose differed between the three types of ion beams and gamma rays. With the $320 \mathrm{MeV}$ carbon ion beam, $100 \mathrm{MeV}$ helium ion beam, and gamma rays, the number of plants with a relative nuclear DNA content below 0.97 increased significantly with increasing irradiation dose (chi-square test for independence, $100 \mathrm{MeV}$ helium ion beam and gamma rays, $P<0.01 ; 320 \mathrm{MeV}$ carbon ion beam, $P<0.05)$, and the average nuclear DNA content decreased significantly (Kruskal-Wallis test, $P<0.01$ ). On the other hand, with the $220 \mathrm{MeV}$ carbon ion beam, the average nuclear DNA content did not decrease and the number of plants with a relative nuclear DNA content below 0.97 did not increase, even when the irradiation dose increased.

To clarify the difference in the influence of irradiation on the nuclear DNA content among the three types of ion beams and gamma rays, we compared the nuclear DNA content at each irradiation dose that gave an approximately 50\% regeneration rate: $3 \mathrm{~Gy}$ of the $220 \mathrm{MeV}$ carbon ion beam, $5 \mathrm{~Gy}$ of the $320 \mathrm{MeV}$ carbon ion beam, $10 \mathrm{~Gy}$ of the $100 \mathrm{MeV}$ helium ion beam, and $20 \mathrm{~Gy}$ of gamma rays. At $3 \mathrm{~Gy}$ of the $220 \mathrm{MeV}$ carbon ion beam and $20 \mathrm{~Gy}$ of gamma rays, the average nuclear DNA content was 0.98 and the number of plants with a relative nuclear DNA content below 0.97 was similar: 23 and 21 out of 50 plants, respectively. In contrast, the average nuclear DNA content was 0.96 at $5 \mathrm{~Gy}$ of the $320 \mathrm{MeV}$ carbon ion beam and $10 \mathrm{~Gy}$ of the $100 \mathrm{MeV}$ helium ion beam. The number of plants with a relative nuclear DNA content below 0.97 was 38 and 41 out of 50 plants, respectively. Thus, the influence of the $320 \mathrm{MeV}$ carbon ion beam and the $100 \mathrm{MeV}$ helium ion beam on nuclear DNA content was larger than that of the $220 \mathrm{MeV}$ carbon ion beam and gamma rays.

\section{Relationship between plant size and nuclear DNA content}

There was a significant correlation between the nuclear DNA content and leaf length in plants obtained from treatment with $220 \mathrm{MeV}$ carbon ion beam $(\mathrm{r}=0.472, P<0.01)$ or gamma rays $(\mathrm{r}=0.427, P<0.01)$; the smaller the nuclear DNA content, the shorter the leaf length (Fig. 3). Leaves of the plants with decreased nuclear DNA content were smaller, as demonstrated by the significant correlation of leaf length with leaf width $(\mathrm{r}=0.915, P<0.01)$ (data not shown). The diameter of inflorescences was significantly correlated with the nuclear DNA content for the gamma ray treatment $(\mathrm{r}=0.608, P<0.01)$. The diameter of inflorescences showed a tendency to decrease with decreasing nuclear DNA content using the $220 \mathrm{MeV}$ carbon ion beam treatment $(\mathrm{r}=0.290)$. The regression slopes of the nuclear DNA content and diameter of inflorescences show a significant difference between the $220 \mathrm{MeV}$ carbon ion beam and gamma ray treatments $(\mathrm{t}=2.432, P<0.05)$.

\section{Mutation frequency}

The frequency of flower color mutations increased with increasing irradiation dose in all types of irradiation (Fig. 4). The dose required to obtain the same mutation frequency increased in the following order: $220 \mathrm{MeV}$ carbon ion beam $<320 \mathrm{MeV}$ carbon ion beam $<100 \mathrm{MeV}$ helium ion beam $<$ gamma rays. Thus, as LET rose, the mutation frequency per dose increased. The frequency of spontaneous flower color mutation for the tissue culture method used in this study was $0.6 \%$ (Yamaguchi et al. 2008).

To compare mutation frequencies among the ion beams and gamma rays, the relationships between the mutation frequency and regeneration rate (Fig. 5), and the mutation frequency and nuclear DNA content (Fig. 6) were investigated. When based on regeneration rate, the mutation frequencies
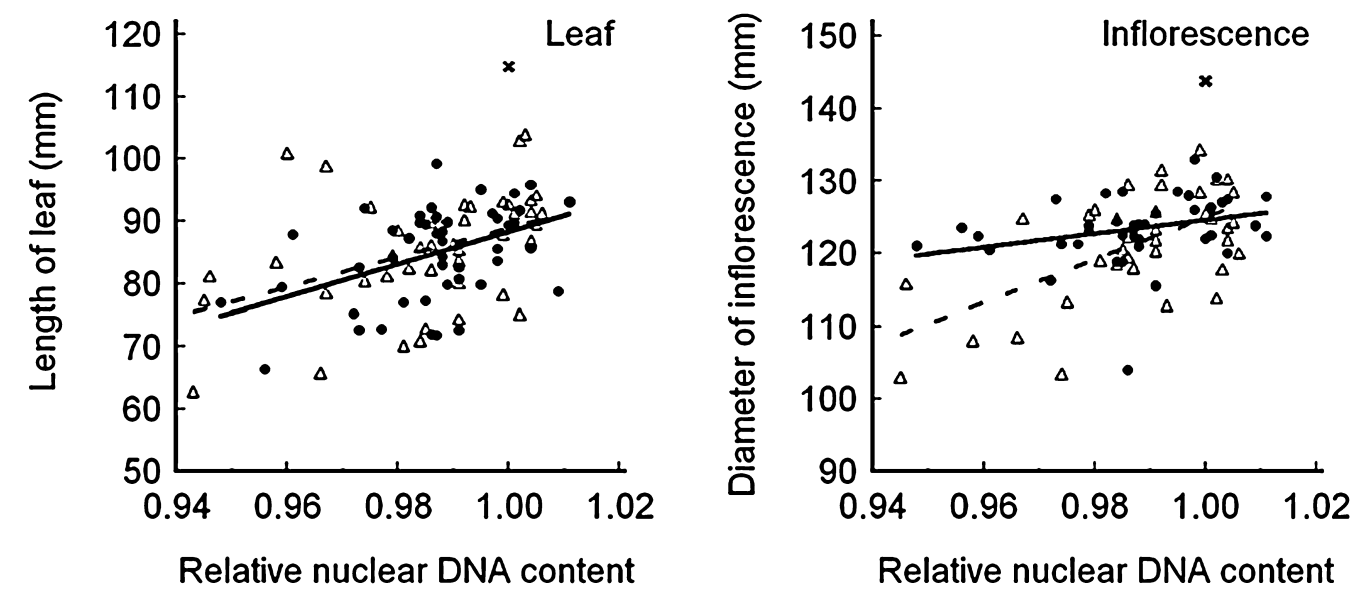

Fig. 3. Relationship between nuclear DNA content and length of leaf diameter of inflorescence in chrysanthemum. ion beam, leaf; $\mathrm{y}=-171+259 \mathrm{x}, \mathrm{r}=0.472^{* *}$, inflorescence; $\mathrm{y}=30.3+94.1 \mathrm{x}, \mathrm{r}=0.290 ; \triangle$, dotted line: gamma rays, leaf; $\mathrm{y}=-146+235 \mathrm{x}$, $\mathrm{r}=0.427^{* *}$, inflorescence; $\mathrm{y}=-167+292 \mathrm{x}, \mathrm{r}=0.608^{* *} ; \mathrm{x}$ : control plant, **: Significant at $1 \%$ level. 


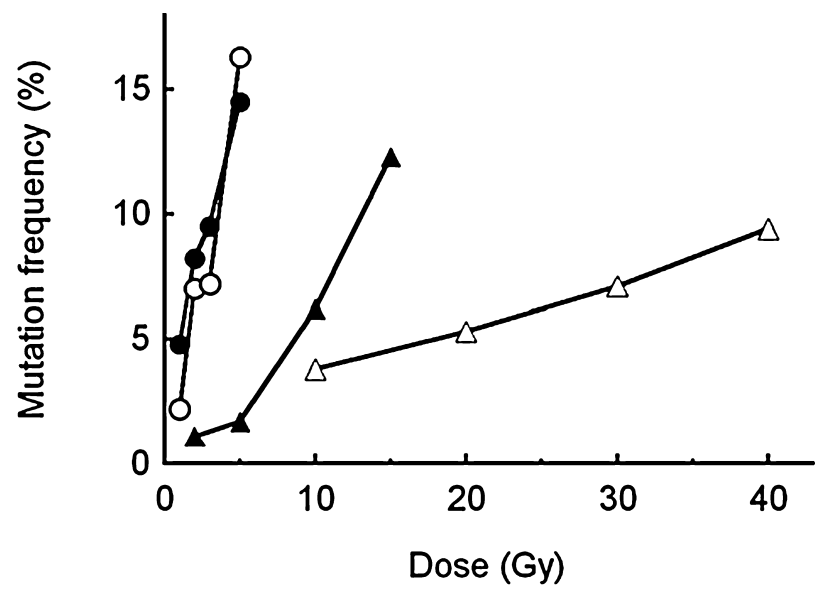

Fig. 4. Effect of ion beam and gamma ray irradiation on frequency of flower color mutations in chrysanthemum. $220 \mathrm{MeV}$ carbon ion beam; $\bigcirc: 320 \mathrm{MeV}$ carbon ion beam; $\boldsymbol{\Delta}: 100 \mathrm{MeV}$ helium ion beam; $\triangle$ : gamma rays.

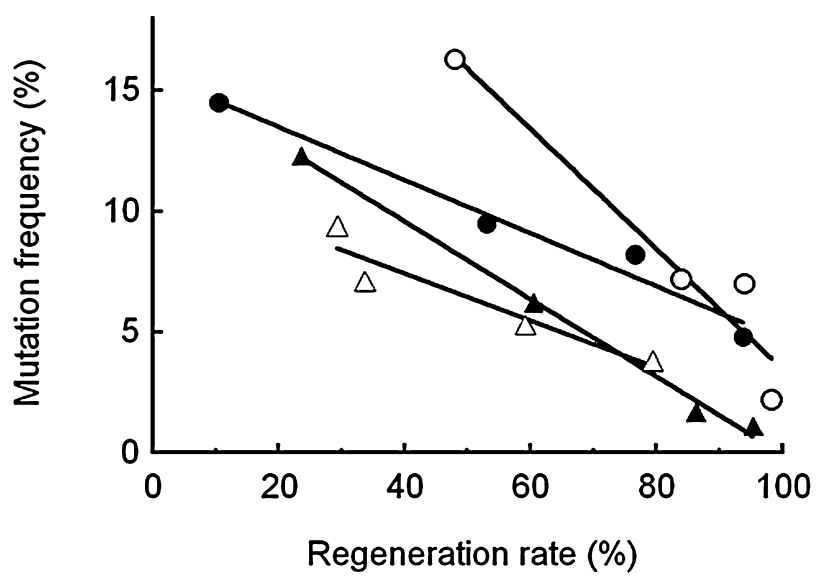

Fig. 5. Relationship between regeneration rate and frequency of flower color mutations in chrysanthemum. O: $220 \mathrm{MeV}$ carbon ion beam, $\mathrm{y}=15.7-0.110 \mathrm{x}, \mathrm{r}=-0.986^{*} ; \bigcirc: 320 \mathrm{MeV}$ carbon ion beam, $\mathrm{y}=28.3-0.249 \mathrm{x}, \mathrm{r}=-0.965^{*} ; \boldsymbol{\Delta}: 100 \mathrm{MeV}$ helium ion beam, $\mathrm{y}=16.0-0.161 \mathrm{x}, \mathrm{r}=-0.998^{* *} ; \triangle$ : gamma rays, $\mathrm{y}=11.3-0.0975 \mathrm{x}$, $\mathrm{r}=-0.945 . *$ and $* *$ Significant at $5 \%$ and $1 \%$ levels, respectively.

of the ion beams were usually higher than that of gamma rays. On the other hand, when based on the reduction in the nuclear DNA content, the mutation frequencies due to the $220 \mathrm{MeV}$ carbon ion beam, $320 \mathrm{MeV}$ carbon ion beam, and gamma rays were similar, whereas those of the $100 \mathrm{MeV}$ helium ion beam were lower than those of the other radiations.

\section{Spectrum of flower color mutations}

Eleven types of flower color mutants were obtained from the donor cultivar 'Taihei,' which has a pink flower color. The number of each type obtained with each treatment is shown in Table 1. No ion beam- or gamma ray-specific mutant emerged, and there was no difference in the relative frequencies of each flower color mutation, but we were unable to perform statistical analysis to verify this hypothesis because the number of each type of flower color mutant was too small.

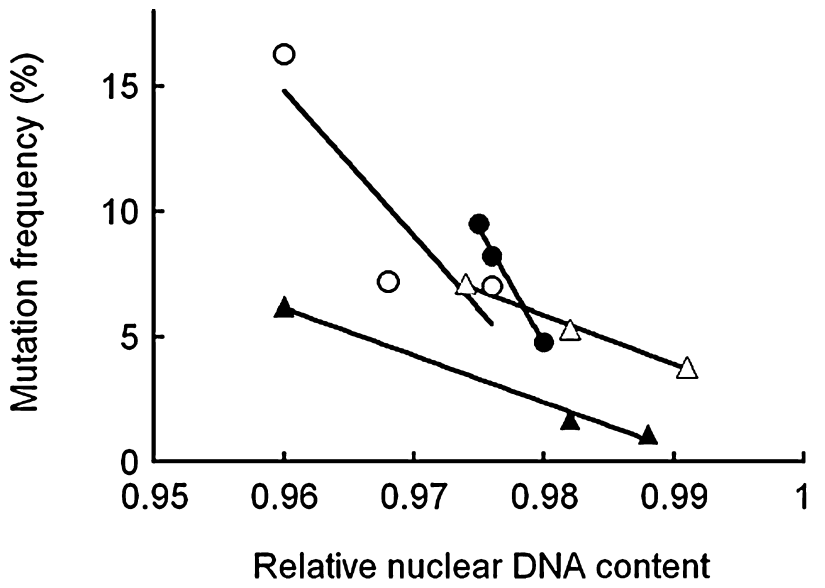

Fig. 6. Relationship between nuclear DNA content and frequency of flower color mutations in chrysanthemum. $0220 \mathrm{MeV}$ carbon ion beam, $\mathrm{y}=900-914 \mathrm{x}, \mathrm{r}=-0.997 * ; \bigcirc: 320 \mathrm{MeV}$ carbon ion beam, $\mathrm{y}=572-581 \mathrm{x}, \mathrm{r}=-0.875 ; \boldsymbol{\Delta}: 100 \mathrm{MeV}$ helium ion beam, $\mathrm{y}=187-$ $188 \mathrm{x}, \mathrm{r}=-0.995 ; \triangle:$ gamma rays, $\mathrm{y}=196-194 \mathrm{x}, \mathrm{r}=-0.996 .{ }^{*}$ Significant at $5 \%$ level.

\section{Discussion}

There were differences in the mutation induction effect and nuclear DNA content, that is, radiation damage due to the three types of ion beams and gamma rays. In addition, the relationships between mutation induction and reduction in nuclear DNA content also differed.

Flower color mutants, which did not have reduced nuclear DNA content, were observed (data not shown), indicating that a reduction in the nuclear DNA content was not essential for flower color mutations. A decrease in the nuclear DNA content is undesirable in chrysanthemum, because it is correlated to reduction of inflorescence diameter as well as the chromosome number. Consequently, radiation that induces mutations at high frequency with little influence on the nuclear DNA content is desirable for chrysanthemum breeding. Thus, the $220 \mathrm{MeV}$ carbon ion beam was the most suitable among the three types of ion beams used in this study. Mutation frequency with the $220 \mathrm{MeV}$ carbon ion beam was not low compared to the other ion beams and gamma rays (Fig. 4, Fig. 5 and Fig. 6), while there was little reduction in the nuclear DNA content as the irradiation dose increased (Fig. 2). In contrast, when the irradiation dose of the $100 \mathrm{MeV}$ helium ion beam increased, the nuclear DNA content reduced, although the mutation frequency did not increase compared to the other treatments. Gamma rays are considered to be suitable for obtaining mutants with less radiation damage (Fig. 6).

In our study, the $320 \mathrm{MeV}$ carbon ion beam LET $76 \mathrm{keV} /$ $\mu \mathrm{m}$ was the most effective in inducing flower color mutants (Fig. 4 and Fig. 5). Whereas, in an experiment carried out using the same ion beams, the $100 \mathrm{MeV}$ helium ion beam LET $9 \mathrm{keV} / \mu \mathrm{m}$ was the most effective for inducing chlorophyll mutants in rice (Yamaguchi et al. 2009). Kazama et al. (2008) reported that the mutation induction effect was LET- 
Table 1. Type and number of flower color mutants induced by ion beam and gamma ray irradiation

\begin{tabular}{|c|c|c|c|c|c|c|c|c|c|c|c|c|c|c|}
\hline & \multirow[b]{2}{*}{$\begin{array}{l}\text { Dose } \\
\text { (Gy) }\end{array}$} & \multirow[b]{2}{*}{$\begin{array}{c}\text { No. of in- } \\
\text { vestigated } \\
\text { plants }\end{array}$} & \multicolumn{12}{|c|}{ No. of flower color mutants } \\
\hline & & & $\begin{array}{l}\text { Pale } \\
\text { pink }\end{array}$ & $\begin{array}{l}\text { Rather } \\
\text { pale pink }\end{array}$ & $\begin{array}{l}\text { Deep } \\
\text { pink }\end{array}$ & White & $\begin{array}{l}\text { Pinkish } \\
\text { white }\end{array}$ & Yellow & $\begin{array}{l}\text { Grayish } \\
\text { yellow }\end{array}$ & Orange & $\begin{array}{c}\text { Deep } \\
\text { orange }\end{array}$ & $\begin{array}{l}\text { Pale pink/ } \\
\text { yellow* }\end{array}$ & $\begin{array}{l}\text { Grayish } \\
\text { yellow/ } \\
\text { yellow* }\end{array}$ & Other \\
\hline \multirow{4}{*}{$\begin{array}{l}220 \mathrm{MeV} \text { carbon } \\
\text { ion beam }\end{array}$} & 5 & 159 & 5 & 0 & 0 & 5 & 2 & 0 & 2 & 6 & 0 & 0 & 3 & 0 \\
\hline & 3 & 337 & 9 & 5 & 0 & 4 & 3 & 0 & 1 & 6 & 2 & 0 & 2 & 0 \\
\hline & 2 & 354 & 11 & 1 & 0 & 5 & 4 & 0 & 1 & 4 & 1 & 0 & 2 & 0 \\
\hline & 1 & 330 & 1 & 2 & 0 & 5 & 2 & 0 & 1 & 4 & 1 & 0 & 0 & 0 \\
\hline \multirow{4}{*}{$\begin{array}{l}320 \mathrm{MeV} \text { carbon } \\
\text { ion beam }\end{array}$} & 5 & 239 & 10 & 1 & 2 & 2 & 6 & 0 & 7 & 10 & 0 & 1 & 0 & 0 \\
\hline & 3 & 320 & 7 & 0 & 1 & 3 & 2 & 0 & 3 & 1 & 6 & 0 & 0 & 0 \\
\hline & 2 & 287 & 7 & 1 & 1 & 1 & 0 & 0 & 4 & 5 & 1 & 0 & 0 & 0 \\
\hline & 1 & 268 & 1 & 0 & 0 & 0 & 0 & 0 & 2 & 0 & 3 & 0 & 0 & 0 \\
\hline \multirow{4}{*}{$\begin{array}{l}100 \mathrm{MeV} \text { helium } \\
\text { ion beam }\end{array}$} & 15 & 138 & 6 & 3 & 0 & 1 & 2 & 0 & 1 & 2 & 1 & 0 & 0 & 1 \\
\hline & 10 & 225 & 2 & 1 & 0 & 6 & 1 & 1 & 0 & 2 & 1 & 0 & 0 & 0 \\
\hline & 5 & 291 & 2 & 0 & 0 & 0 & 0 & 0 & 0 & 3 & 0 & 0 & 0 & 0 \\
\hline & 2 & 275 & 2 & 0 & 0 & 0 & 0 & 0 & 0 & 1 & 0 & 0 & 0 & 0 \\
\hline \multirow[t]{4}{*}{ Gamma rays } & 40 & 128 & 3 & 1 & 1 & 1 & 0 & 0 & 0 & 1 & 4 & 0 & 1 & 0 \\
\hline & 30 & 184 & 3 & 0 & 1 & 1 & 2 & 0 & 1 & 5 & 0 & 0 & 0 & 0 \\
\hline & 20 & 244 & 4 & 1 & 0 & 2 & 0 & 0 & 0 & 3 & 0 & 0 & 3 & 0 \\
\hline & 10 & 399 & 6 & 0 & 0 & 2 & 1 & 0 & 2 & 2 & 0 & 0 & 2 & 0 \\
\hline Non irradiation & & 937 & 2 & 0 & 0 & 0 & 0 & 0 & 0 & 0 & 0 & 1 & 2 & 1 \\
\hline
\end{tabular}

*: color of outer ray floret/color of inner ray floret.

dependent regardless of ion species. Therefore, it is possible that the difference in the most effective ions among the experiments was not due to ion species but due to LET of each ion beam. Kazama et al. (2008) reported that LET of $30 \mathrm{KeV} / \mu \mathrm{m}$ was the most effective for inducing albino mutants in the $\mathrm{M}_{2}$ generation of Arabidopsis. Consequently, it is possible that the optimum LET for mutation induction differs among species.

A new mutagen is expected to induce novel mutants. In carnations (Okamura et al. 2003) and chrysanthemums (Nagatomi et al. 1998), ion-beam-specific flower color mutants, which are not obtained using gamma rays, were induced by ion beams. In contrast, Yamaguchi et al. (2009) reported that no remarkable difference was observed in the relative frequencies of the three types of chlorophyll mutations (albina, xantha, and viridis) in rice among ion beams and gamma rays. In our study, the spectrum did not seem to differ among ion beams and gamma rays because no ionbeam- nor gamma-ray-specific mutant was observed, and there was no difference in the relative frequencies of each flower color mutation.

We did not obtain any ion-beam-specific mutants as described by Nagatomi et al. (1998) despite using the same chrysanthemum variety 'Taihei.' Nagatomi et al. (2000) reported that the frequency of flower color mutations differed according to the irradiated plant materials. Flower color mutants were obtained at a higher frequency when cultured petals were irradiated rather than cultured leaves. This result suggests that mutagenesis in genes related to flower color differs between petal and leaf. Nagatomi et al. (1998) used petals while we used leaves in this study, which may be the reason for not obtaining ion-beam-specific flower color mutants in our study.

The nuclear DNA content as well as chromosome number (Dowrick and Bayoumi 1966, Ichikawa et al. 1970) were correlated with plant size, though there was a difference in the relationship between the decrease in the nuclear DNA content and reduction of inflorescence diameter between the $220 \mathrm{MeV}$ carbon ion beam and gamma rays (Fig. 3). Roux et al. (2003) suggested that the use of flow cytometry may contribute to rejection of mutants with undesirable agromorphological traits in Musa. Flow cytometry can be used to estimate radiation damage in chrysanthemums and facilitate the rejection of mutants with severe radiation damage that results in smaller plants.

Ion beams have been widely used to induce mutations, but there are few reports comparing their characteristics to those of gamma rays. Further investigations through mutation breeding programs of various crops are necessary to clarify the characteristics of the effects of ion beams.

\section{Acknowledgments}

Part of this study was financially supported by the Budget for Nuclear Research of the Ministry of Education, Culture, Sports, Science and Technology, based on screening and counseling by the Atomic Energy Commission.

\section{Literature Cited}

Affrida, A.H., A.Sakinah, A.Zaiton, B. Mohd Nazir, A.Tanaka, I. Narumi, Y.Oono and Y.Hase (2008) Mutation induction in orchids using ion beams. JAEA Takasaki Ann. Rep. 2007: 61.

Barker, R.E., J.A.Kilgore, R.L.Cook, A.E. Garay and S.E.Warnke (2001) Use of flow cytometry to determine ploidy level of 
ryegrass. Seed Sci. \& Technol. 29: 493-502.

Bashir,A., J.A.Auger and A.L.Rayburn (1993) Flow cytometric DNA analysis of wheat-rye addition lines. Cytometry 14: 843-847.

Chinone,S., K. Tokuhiro, K.Nakatsubo, Y.Hase and I.Narumi (2008) Mutation induction on Delphinium and Limonium sinuatum irradiated with ion beams. JAEA Takasaki Annual Report 2007: 68.

Dowrick,G.J. and A.El-Bayoumi (1966) The induction of mutations in chrysanthemum using $\mathrm{X}$ - and gamma radiation. Euphytica 15 : 204-210.

Furutani,N., A.Matsumura, Y.Hase, R.Yoshihara and I.Narumi (2008) Dose response and mutation induction by ion beam irradiation in chrysanthemum. JAEA Takasaki Ann. Rep. 2007: 69.

Hamatani, M., Y. Iitsuka, T. Abe, K. Miyoshi, M. Yamamoto and S.Yoshida (2001) Mutant flowers of dahlia (Dahlia pinnata Cav.) induced by heavy-ion beams. RIKEN Accel. Prog. Rep. 34: 169.

Hara, Y., T.Abe, K.Sakamoto, Y.Miyazawa and S. Yoshida (2003) Effects of heavy-ion beam irradiation in rose (Rosa Hybrid cv. 'Bridal Fantasy'). RIKEN Accel. Prog. Rep. 36: 135.

Hase, Y., A.Tanaka, T.Baba and H.Watanabe (2000) FRL1 is required for petal and sepal development in Arabidopsis. Plant J. 24: 21-32.

Ichikawa,S., K. Yamakawa, F.Sekiguchi and T.Tatsuno (1970) Variation in somatic chromosome number found in radiation-induced mutants of Chrysanthemum morifolium Hemsl. cv. Yellow Delaware and Delaware. Rad. Bot. 10: 557-562.

Iizuka,M., R. Yoshihara and Y.Hase (2008) Development of commercial variety of osteospermum by a stepwise mutagenesis by ion beam irradiation. JAEA Takasaki Ann. Rep. 2007: 65.

Kanaya,T., H.Saito, Y.Hayashi, N.Fukunishi, H.Ryuto, K.Miyazaki, T.Kusumi, T.Abe and K.Suzuki (2008) Heavy-ion beam-induced sterile mutants of verbena (Verbena hybrida) with an improved flowering habit. Plant Biotechnol. 25: 91-96.

Kazama,Y., H.Saito, Y.Yamamoto, Y.Hayashi, H.Ichida, H.Ryuto, N.Fukunishi and T.Abe (2008) LET-dependent effects of heavyion beam irradiation in Arabidopsis thaliana. Plant Biotechnol. 25: 113-117.

Konzak,C.F., R.A.Nilan, J.Wagner and R.J.Foster (1965) Efficient chemical mutagenesis, in: The use of induced mutations in plant breeding. Report of the FAO/IAEA technical meeting organized by the food and agriculture organization of the United Nations and the International Atomic Energy Agency in cooperation with the European Association for Research on Plant Breeding, Rome, Italy, 25 May 1964, Pergamon Press, Oxford, pp. 49-70.

Miyazaki, K., K.Suzuki, T.Abe, Y.Katsumoto, S. Yoshida and T. Kusumi (2002) Isolation of variegated mutants of Petunia hybrida using heavy-ion beam irradiation. RIKEN Accel. Prog. Rep. 35: 130 .

Miyazaki,K., K.Suzuki, K.Iwaki, T.Abe, S. Yoshida and H.Fukui (2006) Flower pigment mutations induced by heavy ion beam irradiation in an inter specific hybrid of Torenia. Plant Biotechnol. 23: 163-167.

Murashige,T. and F.Skoog (1962) A revised medium for rapid growth and bio-assays with tobacco tissue culture. Physiol. Plant. 15: 473491.

Nagatomi, S., A.Tanaka, A.Kato, H. Yamaguchi, H. Watanabe and S.Tano (1998) Mutation induction through ion beam irradiations in rice and chrysanthemum. TIARA Ann. Rep. 1997: 41-43.

Nagatomi,S., E.Miyahira and K.Degi (2000) Induction of flower mutation comparing with chronic and acute gamma irradiation using tissue culture techniques in Chrysanthemum morifolium. Ramat. Acta Horticulturae. 508: 69-73.

Nagatomi, S., H. Watanabe, A.Tanaka, H. Yamaguchi, K. Degi and T.Morishita (2003) Six mutant varieties induced by ion beams in chrysanthemum. Institute of Radiation Breeding, Technical News 65
Okamura, M., N. Yasuno, M. Ohtsuka, A.Tanaka, N. Shikazono and Y.Hase (2003) Wide variety of flower-color and -shape mutants regenerated from leaf cultures irradiated with ion beams. Nucl. Instr. and Meth. in Phys. Res. B 206: 574-578.

Pfosser,M., A.Amon, J.Lafferty, E.Heberle-Bors and T.Lelley (1995) Gain or loss of single chromosomes in wheat-rye addition lines and in 6x triticale detected by flow cytometry. Plant Breed. 114: 555557

Roux,N., A.Toloza, Z.Radecki, F.J.Zapata-Arias and J.Dolezel (2003) Rapid detection of aneuploidy in Musa using flow cytometry. Plant Cell Rep. 21: 483-490.

Sasaki, K., R.Aida, T.Niki, H. Yamaguchi, T.Narumi, T.Nishijima, Y.Hayashi, H.Ryuto, N.Fukunishi, T.Abe and N.Ohtsubo (2008) High-efficiency improvement of transgenic torenia flowers by ion beam irradiation. Plant Biotechnol. 25: 81-89.

Shikazono,N., Y.Yokota, S.Kitamura, C.Suzuki, H. Watanabe, S.Tano and A.Tanaka (2003) Mutation rate and novel $t t$ mutants of Arabidopsis thaliana induced by carbon ions. Genetics 163: 14491455 .

Shirao, T., K.Ueno, K.Minami, A.Tanaka, S.Imakiire, Y.Hase and A. Tanaka (2007) Ion beam breeding of chrysanthemum cultivar 'Sanyo-ohgon'. JAEA Takasaki Ann. Rep. 2006: 74

Sugiyama,M., Y.Hayashi, N.Fukunishi, H.Ryuto, T.Terakawa and T.Abe (2008) Development of flower color mutant of Dianthus chinensis var. semperflorens by heavy-ion beam irradiation. RIKEN Accel. Prog. Rep. 41: 229.

Sugiyama,M., H.Saito, H.Ichida, Y.Hayashi, H.Ryuto, N.Fukunishi, T. Terakawa and T.Abe (2008) Biological effects of heavy-ion beam irradiation on cyclamen. Plant Biotechnol. 25: 101-104.

Suzuki,K., Y.Takatsu, T.Gonai, M.Nogi, K.Sakamoto, N.Fukunishi, H.Ryuto, H.Saito, T.Abe, S. Yoshida and M.Kasumi (2005) Flower color mutation in spray-type chrysanthemum (Dendranthema grandiflorum (Ramat.) Kitamura) induced by heavy-ion beam irradiation. RIKEN Accel. Prog. Rep. 38: 138.

Tanaka, A., S. Tano, T. Chantes, Y. Yokota, N. Shikazono and H.Watanabe (1997) A new Arabidopsis mutant induced by ion beams affects flavonoid synthesis with spotted pigmentation in testa. Genes Genet. Syst. 72: 141-148.

Tanaka, A., A.Sakamoto, Y.Ishigaki, O.Nikaido, G.Sun, Y.Hase, N.Shikazono, S.Tano and H.Watanabe (2002) An ultraviolet-Bresistant mutant with enhanced DNA repair in Arabidopsis. Plant Physiol. 129: 64-71.

Ueno, K., T.Shirao, S.Nagayoshi, Y.Hase and A.Tanaka (2005) Additional improvement of Chrysanthemum using ion beam reirradiation. TIARA Ann. Rep. 2004: 60.

Yamaguchi,H., S. Nagatomi, T.Morishita, K.Degi, A. Tanaka, N. Shikazono and Y.Hase (2003) Mutation induced with ion beam irradiation in rose. Nucl. Instr. Meth. In Phys. Res. B 206: 561-564.

Yamaguchi,H., A.Shimizu, K.Degi and T.Morishita (2008) Effects of dose and dose rate of gamma ray irradiation on mutation induction and nuclear DNA content in chrysanthemum. Breed. Sci. 58: 331335 .

Yamaguchi,H., Y.Hase, A.Tanaka, N.Shikazono, K.Degi, A.Shimizu and T.Morishita (2009) Mutagenic effects of ion beam irradiation on rice. Breed. Sci. 59: 169-177.

Wakita, N., Y. Kazama, Y.Hayashi, H. Ryuto, N. Fukunishi, K. Yamamoto, S.Ijichi and T.Abe (2008) Induction of floral-color mutation by $\mathrm{C}$-ion irradiation in spray-type chrysanthemum. RIKEN Accel. Prog. Rep. 41: 230.

Watanabe,H., T.Toyota, K.Emoto, S. Yoshimatsu, Y.Hase and S. Kamisoyama (2008) Mutation breeding of a new chrysanthemum variety by irradiation of ion beams to 'Jinba.' JAEA Takasaki Ann. Rep. 2007: 81 . 